\title{
Effect of natural antioxidants from grape seed and chestnut in combination with hydroxytyrosol, as sodium nitrite substitutes in Cinta Senese dry-fermented sausages
}

\author{
Chiara Aquilani $^{\mathrm{a}, *}$, Francesco Sirtori ${ }^{\mathrm{a}}$, Monica Flores ${ }^{\mathrm{b}}$, Riccardo Bozzi ${ }^{\mathrm{a}}$, Benedicte Lebret ${ }^{\mathrm{c}}$, \\ Carolina Pugliese $^{\mathrm{a}}$ \\ ${ }^{\text {a } D I S P A A ~-~ D e p a r t m e n t ~ o f ~ A g r i f o o d ~ P r o d u c t i o n ~ a n d ~ E n v i r o n m e n t a l ~ S c i e n c e s, ~ A n i m a l ~ S c i e n c e ~ S e c t i o n, ~ U n i v e r s i t a ' ~ d e g l i ~ S t u d i ~ d i ~ F i r e n z e, ~} 50144$ Firenze, Italy \\ ${ }^{\mathrm{b}}$ IATA - Institute of Agrochemistry and Food Technology (IATA-CSIC), Paterna, Valencia, Spain \\ ${ }^{\mathrm{c}}$ PEGASE, INRA, Agrocampus-Ouest, 35042 Rennes, France
}

A R T I C L E I N F O

\section{Keywords:}

Volatile compounds

Meat quality

GC-olfactometry

Local pig breed

Lipid oxidation

Pork products

\begin{abstract}
A B S T R A C T
Dry-fermented pork sausages, from Cinta Senese local breed, were manufactured replacing sodium nitrite (NIT) with two mixtures of natural antioxidants consisting of: i) grape seed extract and olive pomace hydroxytyrosol (GSE); ii) chestnut extract and olive pomace hydroxytyrosol (CHE). The effects on physical-chemical, aromatic and sensory traits, as well as the microbiological safety, were tested. Nitrite replacement lowered the pH in GSE and CHE samples and resulted in several differences in physical traits between CHE and NIT samples. Listeria monocytogenes, Salmonella and Clostridium botulinum were not found in any samples. GSE and CHE mixtures showed a slightly lower antioxidant activity. Volatile profile showed a similar aromatic profile among the three treatments with differences mainly to abundance of the single compounds, indicating that replacement of nitrite by natural antioxidants did not affect the overall aroma profile, as outlined by olfactometry results. In addition, the replacement did not affect the overall acceptability, except for color-related traits, underscored in GSE and CHE products.
\end{abstract}

\section{Introduction}

Dry cured meat products are typical of the Mediterranean area and they represent a high-value production in European countries, considering that curing process allows extension of meat shelf-life (Marco, Navarro, \& Flores, 2006) and leads to typical pork products with specific eating quality and regional identity (Pugliese \& Sirtori, 2012). In Southern Europe, salami and dry-fermented sausages, are generally characterized by slowly air-drying and mold-ripening (Flores, 1997). This curing process leads to peculiar characteristics and flavors that are widely appreciated by consumers; but is also related to longer curing times that may cause higher lipid oxidation levels. Moreover, natural fermentation, avoiding the addition of lactic acid-producing starter cultures, is more susceptible to the growth of harmful bacteria, such as Listeria monocytogenes or Clostridium botulinum (Lücke, 2000). Thus, to avoid a severe deterioration of nutritive and organoleptic attributes, as well as to ensure food safety, several synthetic food preservatives are commonly included. Among them, the most used are nitrites and nitrates (Hammes, 2012). Nitrite positively affects color, inhibits the growth of pathogenic bacteria, contributes to the development of typical cured meat flavor and delays oxidative rancidity (Marco et al., 2006). Despite their effectiveness as curing agents, the nitrite/nitrate intake represents a risk to human health, i.e. the formation of carcinogenic nitrosamines is one of the most current concerns (De Mey, De Maere, Paelinck, \& Fraeye, 2017). Several studies have focused on nitrate/nitrite reduction or substitution (Özvural \& Vural, 2014; Pateiro, Bermúdez, Lorenzo, \& Franco, 2015; Purriños, García Fontán, Carballo, \& Lorenzo, 2013), but the main issue remains finding an alternative able to address the multiple activities they perform. Up until now, most of the alternatives proposed are plant extracts, largely obtained from agricultural by-products. These compounds are very rich in polyphenols, flavonoids and terpenoids and are able to perform a double antioxidant-antimicrobial functions (Falowo, Fayemi, \& Muchenje, 2014; Hygreeva, Pandey, \& Radhakrishna, 2014; Shah, Bosco, \& Mir, 2014). These compounds might also constitute a great opportunity to exploit agricultural by-products, which otherwise would be wasted. The aim of this study was to assess the feasibility of producing dry-fermented sausages by replacing sodium nitrite with natural antioxidants

\footnotetext{
* Corresponding author.

E-mail address: chiara.aquilani@unifi.it (C. Aquilani).
} 
Table 1

Phenolic profile of olive pomace and defatted grape seed and chestnut extracts.

\begin{tabular}{|c|c|c|c|c|c|}
\hline \multicolumn{2}{|l|}{ Olive pomace $(\mathrm{g} / \mathrm{L})$} & \multicolumn{2}{|l|}{ Grape seed } & \multicolumn{2}{|l|}{ Chestnut } \\
\hline (hydroxytyrosol) & & $(\mathrm{mg} / \mathrm{g})$ & & $(\mathrm{mg} / \mathrm{g})$ & \\
\hline Hydroxytyrosol & 11.65 & Gallic acid & 0.01 & Vescalin & 9.34 \\
\hline Tyrosol \& hydroxytyrosol derived compounds & 15.13 & Catechin B3 (dimers) & 2.22 & Castalin & 8.99 \\
\hline \multirow[t]{15}{*}{ Verbascosid } & 5.84 & Catechin & 11.07 & Pedunculagin I & 3.88 \\
\hline & & Catechin (trimers) & 3.21 & Monogalloil glucose I & 3.58 \\
\hline & & Catechin B6 (dimers) & 2.61 & Gallic acid & 18.50 \\
\hline & & Catechin B2 (dimers) & 5.37 & Monogalloil glucose II & 2.73 \\
\hline & & Epicatechin & 13.62 & Roburin D & 10.51 \\
\hline & & Catechina trimer & 3.71 & Vescalagin & 32.15 \\
\hline & & Epicatechin gallate (PM 730) & 6.65 & $C$-glucoside tergallic dehydrate & 2.73 \\
\hline & & Epicatechin gallate (PM 442) & 6.10 & Castalagin & 31.03 \\
\hline & & Oligomers (tetramers) & 54.88 & Digalloil glucose I & 10.03 \\
\hline & & Epicatechin gallate (PM 882) & 180.65 & Digalloil glucose II & 2.09 \\
\hline & & Epicatechin gallate oligomers (trimers) & 382.97 & Hydrolyzable tannin $m / z 1085$ & 8.05 \\
\hline & & Epicatechin gallate oligomers (trimers) & 149.66 & Trigalloil glucose I & 4.61 \\
\hline & & & & Trigalloil glucose II & 6.74 \\
\hline & & & & Tetragalloil glucose & 2.05 \\
\hline & & & & Ellagic acid & 4.08 \\
\hline
\end{tabular}

while trying to maintain quality traits. Grape seed extract, chestnut extract and hydroxytyrosol (extracted from defatted olive pomace), were chosen due to their great availability as by-products of important Tuscan agricultural products. Moreover, among the investigated plant extracts, they have shown an interesting potential both for antioxidant activity and microbial inhibition. This innovation also aimed to valorize Cinta Senese, a local pig breed strongly linked to the Tuscan region.

\section{Materials and methods}

\subsection{Antioxidant mixtures}

The natural antioxidants employed in the present studies were provided by Phytolab (Sesto Fiorentino, Florence, Italy). They consisted of grape seed and chestnut extracts, tocopherol and hydroxytyrosol (extracted by defatted olive pomace). The manufacturer provided the phenolic profile (Table 1), total phenolic content and antiradical scavenging activity $\left(\mathrm{EC}_{50}\right)$ (Table 2 ) of each extract. The grape seed and chestnut extracts were combined with the same amount of hydroxytyrosol and tocopherol to form two different mixtures; grape seed (GSE) and chestnut (CHE) mixtures.

\subsection{Sausages manufacturing}

In an industrial plant (Azienda Agricola Savigni, Pistoia, Italy), $24 \mathrm{~kg}$ of pork lean and $6 \mathrm{~kg}$ of subcutaneous backfat from Cinta Senese pig breed were minced and equally divided in three batches. Salt $(23 \mathrm{~g} /$ $\mathrm{kg})$, sucrose $(35 \mathrm{~g} / \mathrm{kg})$ and black pepper $(0.2 \mathrm{~g} / \mathrm{kg})$ were added to each batch following the recipe traditionally used by the manufacturer. Thirty ppm of sodium nitrite (E250) were added to the first batch to constitute the control (NIT). In second batch, $10 \mathrm{~g} / \mathrm{kg}$ of GSE mixture were used to replace sodium nitrite, while $10 \mathrm{~g} / \mathrm{kg}$ of CHE were added to the third batch. Sausages were weighed, dried at $28^{\circ} \mathrm{C}$ and $\mathrm{RH} 85 \%$

Table 2

Total phenolic content and radical scavenging activity of natural antioxidant constituting the mixtures.

\begin{tabular}{lll}
\hline & $\begin{array}{l}\text { Total phenolic } \\
\text { content }\end{array}$ & $\begin{array}{l}\text { Antiradical scavenging } \\
\text { activity (EC50) }\end{array}$ \\
\hline Grape seed extract & $822.709(\mathrm{mg} / \mathrm{g})$ & 0.147 \\
Chestnut extract & $161.091(\mathrm{mg} / \mathrm{g})$ & 0.085 \\
Olive pomace (hydroxytyrosol) & $32.62(\mathrm{~g} / \mathrm{l})$ & 0.196 \\
$\alpha$-tocopherol & - & 0.184 \\
\hline
\end{tabular}

for 4 days and then ripened 21 days ( $\left.\mathrm{T} 13^{\circ} \mathrm{C}, \mathrm{RH} 70 \%\right)$. Once ripened, six samples of each batch were collected, $\mathrm{pH}$, color, and processing loss were immediately measured. Samples were vacuum packed and stored at $-80^{\circ} \mathrm{C}$ for physical, chemical and aromatic analysis. Another 3 samples of each batch were stored at $4{ }^{\circ} \mathrm{C}$ to be employed for sensory analysis the following day. This design was replicated to have two totally independent batches for each treatment.

\subsection{Physical, chemical and microbiological parameters}

At the end of ripening, physical parameters were assessed on 12 samples of each batch ( 6 for each replication). Sausage $\mathrm{pH}$ was measured at room temperature $\left(20^{\circ} \mathrm{C}\right)$ using a pH meter Crison GLP21 (Barcelona, Spain), the instrument was introduced in a sausage portion. Color ( $\mathrm{L}^{*}, \mathrm{a}^{*}$ and $\mathrm{b}^{*}$ ) was determined by a Minolta Chromameter CR200 (Tokyo, Japan) immediately after slicing. $\mathrm{a}_{\mathrm{w}}$ was measured following the method ISO 21807:2004. Two $10 \mathrm{~mm}$-thick and $10 \mathrm{~mm}$ width slices of each sample, were cut and immediately analyzed at room temperature $\left(22^{\circ} \mathrm{C}\right.$ ), using a Zwick Roell Z2.5 apparatus (Ulm, Germany) with a loading cell of $1 \mathrm{kN}$ at the crosshead speed of $1 \mathrm{~mm} / \mathrm{s}$. Texture profile analysis (TPA) was performed assessing the following parameters: hardness, cohesiveness, gumminess, springiness and chewiness. Moisture was determined by lyophilizing to constant weight $40 \mathrm{~g}$ of sample, according to AOAC methods (1990). Weight loss was measured as the difference between weight at time zero and end of ripening (after 24 days). Total protein, fat and ash contents were determined following AOAC (1990) methods. Lipid oxidation was determined according Vyncke (1970), using a PerkinElmer Lambda EZ150 spectrophotometer (Waltham, MA, USA). Results were expressed as mg of malondialdehyde (MDA) $/ \mathrm{kg}$ of samples. Fatty acids were determined using a Varian GC-430 apparatus equipped with a flame ionization detector (FID) (Palo Alto, CA, USA) as reported by Sirtori et al. (2015). The individual methyl esters were identified by their retention time using an analytical standard (F.A.M.E. Mix, C8-C22 Supelco 18,9201AMP). Response factors based on the internal standard (C19:0) were used for quantification and results were expressed as $\mathrm{mg} / 100 \mathrm{~g}$ of sample. The fatty acid content was reported as saturated (SFA), monounsaturated (MUFA) and polyunsaturated (PUFA) fatty acids. Microbiological analyses were carried out in an external accredited laboratory to determine the products' safety. The following bacteria were investigated: Escherichia coli (ISO 16649-2:2001), Listeria monocytogenes (UNI EN ISO 11290-1:2005), coagulase positive Staphylococcus spp. (UNI EN ISO 6888-1:2004), Clostridium botulinum (ISO 15213:2003) and Salmonella spp. (UNI EN ISO 6579:2008). 


\subsection{Volatile compounds analysis}

\subsubsection{Gas chromatography-mass spectrometry analysis (GC-MS)}

Solid-phase microextraction (SPME) and GC-MS analysis were performed following the method described by Corral, Salvador, and Flores (2013) using a $85 \mu \mathrm{m}$ Carboxen/Polydimethylsiloxane (CAR/ PDMS) fiber (Supelco, Bellefonte, PA) installed in a Gerstel MPS2 multipurpose sampler (Gerstel, Germany) and an Agilent HP 7890 series II GC with an HP 5975C mass selective detector (Hewlett-Packard Palo Alto, CA, USA). The volatile compounds (VOCs) detected were identified by comparison with mass-spectra from the library database (Nist'05), linear retention index (van Den Dool \& Dec. Kratz, 1963) and by comparison with authentic standards. The quantification of volatile compounds was done in SCAN mode using either total or extracted ion chromatogram (TIC or EIC) on an arbitrary scale.

\subsubsection{Gas chromatrography-olfactometry analysis (GC-O)}

A gas chromatograph (Agilent 6890, USA) equipped with an FID detector and sniffing port (ODP3, Gerstel, Mülheim an der Ruhr, Germany) was used to analyze aroma compounds extracted by SPME as described by Corral et al. (2013). The detection frequency (DF) method was used to estimate the aromatic impact of each volatile and each assessment was carried out according to Olivares, Navarro, and Flores (2011). Four trained panelists evaluated the odors from the GC-effluent. Each assessor evaluated 3 sausages for a total of 12 assessments, the final DF was obtained by summing the 12 sniffings. The detection of an odor by less than three assessors was considered noise. Compounds were identified by comparison with mass spectra, with linear retention indices of authentic standards injected in the GC-MS and GC-O, and by coincidence of the assessors' descriptors with those reported by Burdock (2010).

\subsection{Sensory analysis}

Sensory analysis was carried out in an equipped laboratory by 8 trained panelists using a quantitative-descriptive analysis method. Fourteen attributes (grease appearance, abnormal colors, firmness, color uniformity, redness, cured meat flavor, off odor, salty, rancid, off flavor, hardiness, juiciness, aftertaste, general acceptability) were evaluated, each attribute was scored in a $10 \mathrm{~cm}$ non-structured line (Pugliese et al., 2010). Select subjects underwent an introductory session, where the testing procedures and the chosen sensory traits were discussed using two types of comparable commercial products. During three sessions, panelists evaluated a total of 9 sausages ( 3 samples $\times 3$ treatments) identified by an alphanumerical code. The sausages were divided in $0.5 \mathrm{~cm}$-thick $\times 2 \mathrm{~cm}$-diameter slices and two slices of each samples were randomly served to judges at room temperature $\left(20^{\circ} \mathrm{C}\right)$. Panelists were invited to eat a cracker and drink a glass of water between samples.

\subsection{Statistical analysis}

Data were analyzed by SAS software. Two-way ANOVAs were performed on physical and chemical data according to the following model:

$$
\mathrm{Y}_{\mathrm{ijk}}=\mu+\mathrm{T}_{\mathrm{i}}+\mathrm{B}_{\mathrm{j}}+\varepsilon_{\mathrm{ijk}} \text {. }
$$

Where $\mu$ is the mean, $T$ is the $\mathrm{i}^{\text {th }}$ treatment, $B$ is the $\mathrm{j}^{\text {th }}$ batch and $\varepsilon$ is the error. For sensory data, effect of panelist was included in the previous model. The interaction between Treatment and Batch factors was tested but being not significant, it was not included in the model.

Volatile compounds data were also analyzed by a multivariate approach to determine the presence of characteristic compounds able to be allocated to samples among different treatments. A stepwise discriminant analysis (SDA) was first used to reduce the space-variables, selecting the subset of variables that better discriminated groups. Canonical discriminant analysis (CDA) were performed using SDA
Table 3

Microbiological safety parameters on Cinta Sense dry-fermented sausages manufactured with natural antioxidant (GSE = grape seed extract; $\mathrm{CHE}=$ chestnut extract) as replacement of sodium nitrite (NIT).

\begin{tabular}{llll}
\hline & GSE & CHE & NIT \\
\hline Escherichia coli & $<10$ & $<10$ & $<10$ \\
Listeria monocytogenes & - & - & - \\
Coagulase positive Staphilococcus spp. & $<10$ & $<10$ & $<10$ \\
Sulfite-reducing bacteria (Clostridium botulinum) & $<10$ & $1.210^{2}$ & $0.710^{2}$ \\
Salmonella spp. & - & - & - \\
\hline
\end{tabular}

Results are expressed as ufc/g; the symbol “_" indicates that the organism was not present.

selected variables, resulting in 2 new variables, called canonical functions (CAN1, CAN2). They consisted of a series of canonical coefficients (CC) that indicate the partial contribution of each variable in composing the CANs. The greater the CC, the more the variable contributes to CAN composition.

\section{Results and discussion}

\subsection{Physical, chemical and microbiological parameters}

The major foodborne pathogens (Escherichia coli, Listeria monocytogenes, Staphilococcus spp., Clostridium spp. and Salmonella spp.) were absent or below the limit required (Reg CE/2073/05) in all samples (Table 3). Several studies on plant phenolic suggest these components have antimicrobial activity (Fasolato et al., 2016; Kao et al., 2010; Mujić et al., 2014). Further studies are, however, required to determine the effectiveness of the studied antioxidants against the development of the main foodborne pathogens. The $\mathrm{a}_{\mathrm{w}}$ values (Table 4) recorded for GSE and CHE, being below 0.89, contributed to control pathogenic organisms development (Toldrá \& Flores, 2014). Moisture, fat, protein and ash contents and weight loss were not affected by treatment and they were in line with values reported for dry-cured sausages (Olivares, Navarro, \& Flores, 2015; Ribas-Agustí et al., 2014; Škrlep, Čandek-Potokar, Tomažin, Batorek Lukač, \& Flores, 2017), except for weight loss, which was slightly greater in the present study; likely the smaller diameter of samples could have enhanced the water loss during ripening. The $\mathrm{pH}$ observed was in the range reported for

Table 4

Physical and chemical parameters on Cinta Sense dry-fermented sausages manufactured with natural antioxidant as replacement of sodium nitrite.

\begin{tabular}{|c|c|c|c|c|c|}
\hline & GSE & CHE & NIT & SEM $^{\mathrm{a}}$ & $\mathrm{P}^{\mathrm{b}}$ \\
\hline $\mathrm{pH} 0$ days & 6.13 & 6.40 & 6.35 & 0.05 & n.s. \\
\hline pH 24 days & $6.02 b$ & $6.04 \mathrm{~b}$ & $6.10 \mathrm{a}$ & 0.04 & $* *$ \\
\hline $\mathrm{a}_{\mathrm{w}}$ & 0.89 & 0.88 & 0.90 & 0.01 & n.s. \\
\hline $\mathrm{L}^{*}$ & 43.21 & 41.67 & 42.37 & 0.67 & n.s. \\
\hline$a^{*}$ & $17.22 \mathrm{a}$ & $15.92 b$ & $18.06 a$ & 0.41 & $* *$ \\
\hline $\mathrm{b}^{*}$ & $5.31 b$ & $4.87 b$ & $6.48 \mathrm{a}$ & 0.21 & $* *$ \\
\hline Weight loss (\%) & 40.23 & 43.30 & 42.92 & 1.35 & n.s. \\
\hline Moisture (\%) & 30.43 & 29.97 & 30.94 & 0.66 & n.s. \\
\hline Fat $(\mathrm{g} / 100 \mathrm{~g} \mathrm{dm})$ & 41.82 & 41.01 & 41.32 & 0.33 & n.s. \\
\hline Protein $(\mathrm{g} / 100 \mathrm{~g} \mathrm{dm})$ & 48.88 & 49.74 & 49.14 & 0.31 & n.s. \\
\hline Ash $(\mathrm{g} / 100 \mathrm{~g} \mathrm{dm})$ & 8.46 & 8.69 & 8.80 & 0.12 & n.s. \\
\hline TBARs (mg MDA $/ \mathrm{kg}$ ) & 1.05 & 0.98 & 0.93 & 0.05 & n.s. \\
\hline SFA (mg/100 g) & 8.05 & 7.57 & 7.71 & 0.23 & n.s. \\
\hline MUFA (mg/100 g) & 9.72 & 9.17 & 9.10 & 0.25 & n.s. \\
\hline PUFA (mg/100 g) & 3.32 & 3.38 & 3.47 & 0.10 & n.s. \\
\hline
\end{tabular}

Values are reported as means of the two replications within the same treatment, where GSE is grape seed extract added group, CHE the chestnut extract added group and NIT the control group added with sodium nitrite.

a Standard error.

b $\mathrm{P}$ value of natural antioxidant effect ${ }^{* *} p<0.01$, ${ }^{*} p<0.05$, different letters in the same row indicate significant differences at $p<0.05$. 
natural fermented meat products at a similar curing time (Özvural \& Vural, 2014; Škrlep et al., 2017); indeed, they were characterized by a higher $\mathrm{pH}$ compared to commercial products (Hospital et al., 2015; Montanari et al., 2018). Moreover, significant differences among treatments were found for $\mathrm{pH}$, with lower values observed for GSE and CHE samples, suggesting that Lactobacillus (LAB) growth, that takes place during the first fermentation phase, could be slightly promoted in these products. Indeed, low or nitrites-free sausages showed an increased presence of LAB (Hospital et al., 2015). Growth of LAB was not, however, assessed in the present experiment, and further studies will be required to assess effects of GSE and CHE. Concerning color attributes, $L^{*}$ was not affected by treatment, $a^{*}$ showed significant greater values in GSE and NIT samples than in CHE ones, while b* was significant higher in NIT compared to the modified products. A change in a* was expected considering the role nitrites play in nitrosomyoglobin formation, the characteristic red curing pigment (Hammes, 2012). Since neither chemical composition nor oxidation resulted in significant differences among groups, a different pathway for red color formation in GSE samples should be considered. A stable red color compound called Zn-protoporphyrin, derived from the substitution of heme iron with zinc, has been observed in Parma ham, an Italian nitrite/nitrate-free ham (Wakamatsu, Nishimura, \& Hattori, 2004a). Up to now, mechanisms leading to its formation are not well-known (Hammes, 2012), but the absence of nitrites, low levels of oxygen, meat endogenous enzymes as well as microorganism, are all factors that may contribute to its formation (Wakamatsu et al., 2004b). Apart from the absence of nitrites, some compounds contained in grape seed extract may have promoted the Zn-protoporphyrin formation for the GSE group, while no formation occurred in the CHE samples. These results are partially in agreement with those reported by Lorenzo, González-Rodríguez, Sánchez, Amado, and Franco (2013), althought their study was conducted on chorizo where pigmentation due to added paprika may have interfered.

According to TPA results (Table 5), cohesiveness, springiness and chewiness were affected by nitrite replacement, being highest in CHE samples, lowest in NIT, whereas GSE samples were similar to both. Since no differences in moisture and weight loss were found among the treatments, the results obtained were attributable basically to the differences in $\mathrm{pH}$, which, declining, causes the aggregation of myofibrillar proteins and leads to gel formation (Lücke, 2000). The higher $\mathrm{pH}$ of NIT samples likely inhibited this phenomenon thus reducing the sausage cohesiveness and chewiness. The results reported are partially in agreement with Lorenzo et al., (Lorenzo et al., 2013), who also noticed the highest chewiness values for chorizo with added chestnut extract and ripened for 19 days, compared to the same product manufactured with GSE or synthetic antioxidant (BHT in this case).

The groups did not differ in SFA, MUFA and PUFA contents. Their relative amounts reflect those of fresh pork composition, slightly richer in MUFA than SFA, with PUFA being approximately a third of either

Table 5

Texture traits of Cinta Sense dry-fermented sausages manufactured with natural antioxidant as replacement of sodium nitrite.

\begin{tabular}{llllll}
\hline & GSE & CHE & NIT & SEM $^{\mathrm{a}}$ & P $^{\mathrm{b}}$ \\
\hline Hardness (N) & 104.93 & 102.82 & 102.68 & 6.38 & n.s. \\
Cohesiveness & $0.38 \mathrm{ab}$ & $0.42 \mathrm{a}$ & $0.35 \mathrm{~b}$ & 0.01 & $* *$ \\
Gumminess & 39.57 & 42.93 & 35.99 & 2.11 & n.s. \\
Springiness & $3.04 \mathrm{ab}$ & $3.26 \mathrm{a}$ & $2.70 \mathrm{~b}$ & 0.13 & ${ }^{*}$ \\
Chewiness (N) & $120.67 \mathrm{ab}$ & $139.55 \mathrm{a}$ & $96.79 \mathrm{~b}$ & 8.36 & ${ }^{* *}$
\end{tabular}

Values are reported as means of the two replications within the same treatment, where GSE is grape seed extract added group, CHE the chestnut extract added group and NIT the control group added with sodium nitrite.

a Standard error.

b $\mathrm{P}$ value of natural antioxidant effect ${ }^{*} * p<0.01$, ${ }^{*} p<0.05$, different letters in the same row indicate significant differences at $p<0.05$.
SFA or MUFA categories (Škrlep et al., 2017). PUFA can also be considered an indicator of meat oxidative status, due to their double bonds being preferred substrates for oxidative reactions (Pateiro et al., 2015). Results suggest that the natural antioxidants employed were as effective as nitrites in control lipid oxidation during manufacturing and ripening. This is supported by TBARs results, showing no significant differences among treatments, however, further studies will be required to evaluate the antioxidant activity during the shelf-life. Nitrites exert their antioxidant activity in cured meat by forming the myoglobin-stable compounds and making the iron inaccessible for oxidation (Riazi, Zeynali, Hoseini, Behmadi, \& Savadkoohi, 2018); phenolic compounds instead, follow different pathways, acting as hydrogen donors. The phenolic hydroxyl groups intercept the free radicals to form stable end-products, interrupting and avoiding further lipid oxidation, especially of unsaturated FAs (Jayaprakasha, Selvi, \& Sakariah, 2003). To the best of our knowledge, few data are available about dry-fermented pork sausages with added natural extracts, but the great variability of these traditional products makes comparisons difficult. The efficacy of hydroxytyrosol in preventing lipid oxidation was reported by Cofrades et al., (Cofrades et al., 2011) for n-3 enriched frankfurters, while Lorenzo et al., (Lorenzo et al., 2013) observed comparable TBARS values in Spanish chorizo with added BHT, grape seed extract or chestnut extract.

\subsection{Volatile profile and olfactometry}

Ninety-one VOCs were identified by HS-SPME-GS-MS (Table 6). The most abundant groups originated from spices (51-61\%) and carbohydrate fermentation (30-39\%), followed by amino acid degradation (6-7\%), while VOCs derived from lipid $\beta$-oxidation and lipid oxidation processes represented $1 \%$ of total extracted areas.

Among the 14 VOCs related to lipid auto-oxidation, 5 showed significant differences with NIT resulting in the lowest, while GSE and CHE products showed intermediate or higher abundances. These VOCs originate by autocatalytic fat oxidation and involves mostly unsaturated fatty acids. Among the identified VOCs, hexanal is of keyimportance to better outline the products' oxidation status. The correlation between this compound and lipid oxidation is well-known and its low perception threshold makes hexanal an important contributor to overall aroma (Marco et al., 2006). The higher hexanal content in GSE and CHE samples than NIT is consistant with TBARs results, suggesting greater PUFA oxidation, even if the extent was limited and did not affect the parameters previously examined. The total lipid auto-oxidation values confirmed these differences, with NIT being the lowest, GSE the highest and CHE similar to both, likely related to a higher EC $_{50}$ for GSE. Hence, even though the phenolic extracts used contributed to maintain lipid oxidation below the perception threshold of rancid flavor, they appeared less effective than nitrites in controlling lipid oxidation. Partially in agreement with this, Purriños et al. (2013) reported grape seed was a less effective antioxidant in chorizo, but on the contrary, chestnut extract was found to have higher antioxidant activity than BHT.

Spice derived VOCs were the major group, due to the use of black pepper. Indeed, limonene, a compound particularly abundant in pepper (Moretti et al., 2004) represented approximately half of the total amount for each treatment. As the same amount of pepper was added to all treatments, differences among the 3 groups might be due to several external factors such as an irregular distribution of the ground pepper in the raw matrix (Montanari et al., 2018), as well as a heterogeneity of the spices themselves caused by different grinding techniques and/or storage times that could have led to differential oxidative status, odorant losses and sensory attribute changes (Liu et al., 2013; Orav, Stulova, Kailas, \& Müürisepp, 2004).

Microbial enzymes degrade free fatty acids through $\beta$-oxidation reactions, generating methyl ketones as final products (Flores et al., 2015). Two VOCs belonging to this group were identified, but significant differences were found only for total abundance, which was 
Table 6

Volatile compounds in Cinta Sense dry-fermented sausages manufactured with natural antioxidant as replacement of sodium nitrite.

\begin{tabular}{|c|c|c|c|c|c|c|c|}
\hline Compound & $\mathrm{LRI}^{\mathrm{a}}$ & $\mathrm{RI}^{\mathrm{b}}$ & GSE & CHE & NIT & SEM $^{\mathrm{c}}$ & $\mathrm{P}^{\mathrm{d}}$ \\
\hline \multicolumn{8}{|l|}{ Lipid auto-oxidation } \\
\hline Pentane & 500 & $\mathrm{a}$ & 0.59 & 0.60 & 0.56 & 0.19 & \\
\hline Propanal & 524 & a & 0.19 & 0.13 & 0.13 & 0.06 & \\
\hline Isopropanol (45) & 539 & - & 1.20 & 0.79 & 1.13 & 0.40 & \\
\hline Hexane & 600 & $\mathrm{a}$ & 0.76 & 0.74 & 0.56 & 0.22 & \\
\hline 1-Propanol & 613 & a & 4.90 & 4.90 & 3.72 & 2.37 & \\
\hline Octane & 800 & a & 4.20 & 3.498 & 3.90 & 0.98 & \\
\hline Propanoic acid (74) & 814 & $\mathrm{a}$ & $0.14 \mathrm{a}$ & $0.05 b$ & $0.02 b$ & 0.05 & $* *$ \\
\hline 1-Pentanol & 827 & a & $0.34 \mathrm{ab}$ & $0.43 a$ & $0.22 \mathrm{~b}$ & 0.16 & $*$ \\
\hline Hexanal & 841 & $\mathrm{a}$ & $2.62 \mathrm{a}$ & $2.27 \mathrm{a}$ & $1.36 \mathrm{~b}$ & 0.27 & $*$ \\
\hline 1-Hexanol & 924 & $\mathrm{a}$ & 0.79 & 0.75 & 0.88 & 0.16 & \\
\hline Decane & 1000 & $\mathrm{a}$ & $1.10 \mathrm{a}$ & $1.26 \mathrm{a}$ & $0.48 \mathrm{~b}$ & 0.18 & $* *$ \\
\hline Dodecane & 1200 & $\mathrm{a}$ & 0.96 & 1.14 & 0.92 & 0.37 & \\
\hline Tridecane & 1300 & a & 0.36 & 0.44 & 0.34 & 0.10 & \\
\hline Tetradecane & 1400 & $\mathrm{a}$ & $0.18 \mathrm{~b}$ & $0.87 \mathrm{a}$ & $0.22 \mathrm{~b}$ & 0.16 & $* *$ \\
\hline Total & & & $19.79 \mathrm{a}$ & 16.19ab & $14.57 b$ & 0.96 & $* *$ \\
\hline \multicolumn{8}{|l|}{ Spices } \\
\hline$\alpha$-Thujene & 934 & $\mathrm{~b}$ & 24.40 & 26.07 & 27.29 & 6.22 & \\
\hline$\alpha$-Pinene & 940 & $\mathrm{a}$ & 17.84 & 19.00 & 17.33 & 3.68 & \\
\hline Sabinene $+\beta$-pinene & 986 & a & 133.28 & 149.70 & 145.97 & 19.83 & \\
\hline$\beta$-Myrcene & 1003 & $\mathrm{a}$ & $37.19 b$ & $53.47 \mathrm{a}$ & $39.01 b$ & 9.25 & $* *$ \\
\hline$\alpha$-Phellandrene (93) & 1019 & $\mathrm{~b}$ & $8.71 b$ & $12.39 \mathrm{a}$ & $9.41 b$ & 2.41 & $* *$ \\
\hline 3-Carene & 1023 & a & 73.20 & 86.24 & 77.49 & 15.77 & \\
\hline$\alpha$-Terpinene & 1035 & a & $3.66 \mathrm{~b}$ & $4.54 a$ & $3.28 \mathrm{~b}$ & 0.78 & $*$ \\
\hline Unknown (57) & 1042 & $\mathrm{~b}$ & 0.17 & 0.16 & 0.14 & 0.11 & \\
\hline Limonene & 1046 & a & $307.31 \mathrm{~b}$ & 401.19a & $289.74 b$ & 60.75 & $* *$ \\
\hline$\beta$-Phellandrene (93) & 1051 & $\mathrm{~b}$ & $13.98 b$ & $19.28 \mathrm{a}$ & $14.42 \mathrm{~b}$ & 3.74 & $*$ \\
\hline p-Cymene (119) & 1052 & $\mathrm{~b}$ & 8.49 & 9.078 & 8.98 & 2.73 & \\
\hline$\beta$-Ocimene & 1067 & $\mathrm{~b}$ & $1.18 \mathrm{~b}$ & $1.87 \mathrm{a}$ & $1.15 \mathrm{~b}$ & 0.44 & $* *$ \\
\hline 4-Carene & 1073 & $\mathrm{~b}$ & 0.21 & 0.27 & 0.22 & 0.12 & \\
\hline Unkwon & 1075 & $\mathrm{~b}$ & $3.21 b$ & $4.28 \mathrm{a}$ & $3.16 \mathrm{~b}$ & 0.93 & $*$ \\
\hline Styrene & 1091 & a & 2.20 & 2.43 & 2.34 & 0.31 & \\
\hline Terpene & 1099 & $\mathrm{~b}$ & 0.95 & 1.46 & 1.35 & 0.31 & \\
\hline Terpinolene & 1101 & $\mathrm{~b}$ & $4.64 b$ & $6.48 \mathrm{a}$ & $4.46 \mathrm{~b}$ & 1.20 & $* *$ \\
\hline Unknown (93) & 1120 & $\mathrm{~b}$ & 0.51 & 0.55 & 0.56 & 0.11 & \\
\hline Linalool (93) & 1150 & a & $0.28 \mathrm{~b}$ & $0.33 \mathrm{a}$ & $0.32 \mathrm{ab}$ & 0.04 & $*$ \\
\hline$\beta$-Terpinene $/ \gamma$-Terpinene & 1158 & $\mathrm{~b}$ & 1.4 & 1.37 & 1.43 & 0.24 & \\
\hline 4-Terpineol & 1231 & a & 2.14 & 2.31 & 2.12 & 0.29 & \\
\hline Estragole & 1249 & a & 1.28 & 1.33 & 1.20 & 0.21 & \\
\hline$\alpha$-terpineol & 1256 & a & 0.82 & 0.91 & 0.88 & 0.13 & \\
\hline$\delta$-Elemene & 1342 & $\mathrm{~b}$ & $3.58 \mathrm{a}$ & $4.19 \mathrm{a}$ & $2.74 b$ & 0.66 & $* *$ \\
\hline$\alpha$-Cubebene & 1348 & $\mathrm{~b}$ & $0.85 a$ & $0.92 \mathrm{a}$ & $0.68 b$ & 0.12 & $* *$ \\
\hline Cyclosativene (161) & 1402 & $\mathrm{~b}$ & $0.02 b$ & $0.04 \mathrm{a}$ & $0.02 b$ & 0.00 & $*$ \\
\hline Copaene (161) & 1406 & $\mathrm{~b}$ & $1.50 \mathrm{a}$ & $1.42 \mathrm{a}$ & $1.16 \mathrm{~b}$ & 0.28 & $*$ \\
\hline$\beta$-Cubabene (161) & 1421 & $\mathrm{~b}$ & $0.20 \mathrm{a}$ & $0.19 \mathrm{a}$ & $0.16 b$ & 0.04 & $*$ \\
\hline$\beta$-Elemene (93) & 1423 & $\mathrm{~b}$ & $0.11 b$ & $0.13 \mathrm{a}$ & $0.09 b$ & 0.04 & $* *$ \\
\hline$\alpha$-Bergamotene & 1433 & $\mathrm{~b}$ & $0.79 a$ & $0.91 \mathrm{a}$ & $0.69 c$ & 0.13 & $* *$ \\
\hline trans- $\alpha$-Bergamotene & 1450 & $\mathrm{~b}$ & 0.67 & 0.84 & 0.76 & 0.18 & \\
\hline$\beta$-Caryophyllene & 1455 & $\mathrm{~b}$ & $107.97 \mathrm{a}$ & $113.01 \mathrm{a}$ & $91.99 \mathrm{~b}$ & 13.04 & $* *$ \\
\hline$\alpha$-Caryophyllene & 1486 & $\mathrm{~b}$ & $4.87 \mathrm{a}$ & $4.99 \mathrm{a}$ & $4.19 \mathrm{~b}$ & 0.68 & $*$ \\
\hline Isocaryophillene & 1498 & $\mathrm{~b}$ & 0.65 & 0.84 & 0.57 & 0.26 & \\
\hline Isolongifolene & 1510 & $\mathrm{~b}$ & $10.64 b$ & $11.05 b$ & $25.91 \mathrm{a}$ & 10.05 & $* *$ \\
\hline Valencene & 1513 & $\mathrm{~b}$ & $0.00 \mathrm{~b}$ & $5.31 \mathrm{a}$ & $0.00 \mathrm{~b}$ & 1.78 & $* *$ \\
\hline$\gamma$-Cadinene & 1518 & $\mathrm{~b}$ & $1.72 \mathrm{~b}$ & $1.89 \mathrm{~b}$ & $2.92 \mathrm{a}$ & 0.56 & $* *$ \\
\hline$\delta$-Cadinene & 1529 & $\mathrm{~b}$ & $0.96 b$ & $1.04 \mathrm{~b}$ & $1.29 \mathrm{a}$ & 0.20 & $* *$ \\
\hline Total & & & $783.55 b$ & $984.05 \mathrm{a}$ & $785.83 b$ & 134.67 & $* *$ \\
\hline \multicolumn{8}{|l|}{ Bacterial metabolism } \\
\hline \multicolumn{8}{|l|}{ Lipid $\beta$-oxidation } \\
\hline 2-Pentanone & 734 & a & 5.64 & 5.96 & 6.92 & 1.79 & \\
\hline 3-Octanone & 1032 & a & 2.23 & 2.51 & 2.63 & 0.65 & \\
\hline Total & & & $7.87 \mathrm{~b}$ & $8.47 \mathrm{ab}$ & $9.55 \mathrm{a}$ & 0.63 & $*$ \\
\hline \multicolumn{8}{|l|}{ Esterase activity } \\
\hline 3-Methyl-1-butanol acetate & 907 & a & 0.59 & 0.49 & 0.51 & 0.12 & \\
\hline \multicolumn{8}{|l|}{ Carbohydrate fermentation } \\
\hline Acetaldehyde & 462 & a & $1.26 \mathrm{a}$ & $0.86 \mathrm{~b}$ & $0.89 b$ & 0.25 & $* *$ \\
\hline Ethyl alcohol & 507 & $\mathrm{a}$ & $6.79 \mathrm{a}$ & $5.65 \mathrm{ab}$ & $3.68 \mathrm{~b}$ & 2.23 & $*$ \\
\hline Acetone & 529 & a & 72.92 & 76.47 & 72.72 & 20.58 & \\
\hline 2,3-Butanedione & 627 & a & $9.76 a$ & $7.47 \mathrm{~b}$ & $7.83 b$ & 2.01 & $*$ \\
\hline 2-Butanone & 632 & a & 241.96 & 287.47 & 332.22 & 91.70 & \\
\hline 2-Butanol & 644 & a & 19.99 & 20.52 & 29.19 & 11.02 & \\
\hline Acetic acid (60) & 720 & a & 11.99 & 12.19 & 7.08 & 5.34 & \\
\hline 1-Butanol (56) & 727 & a & 0.28 & 0.18 & 0.71 & 0.67 & \\
\hline
\end{tabular}

(continued on next page) 
Table 6 (continued)

\begin{tabular}{|c|c|c|c|c|c|c|c|}
\hline Compound & $\mathrm{LRI}^{\mathrm{a}}$ & $\mathrm{RI}^{\mathrm{b}}$ & GSE & CHE & NIT & SEM $^{\mathrm{c}}$ & $\mathrm{P}^{\mathrm{d}}$ \\
\hline 2-Pentanol & 756 & a & 0.49 & 0.43 & 0.38 & 0.15 & \\
\hline 3-Hydroxy-2-butanone & 782 & a & $124.14 \mathrm{a}$ & $89.35 b$ & $136.91 \mathrm{a}$ & 31.84 & $* *$ \\
\hline 2,3-Butanediol (45) & 884 & a & $6.20 \mathrm{a}$ & $1.50 \mathrm{~b}$ & $3.76 \mathrm{~b}$ & 2.92 & $* *$ \\
\hline 2,3-Butanediol (45) & 892 & a & 4.17 & 2.30 & 2.36 & 1.98 & \\
\hline Butanoic acid (60) & 894 & a & $0.52 \mathrm{a}$ & $0.49 a$ & $0.18 \mathrm{~b}$ & 0.254808 & $*$ \\
\hline Total & & & 499.97b & $489.85 b$ & $597.61 \mathrm{a}$ & 23.69 & $* *$ \\
\hline \multicolumn{8}{|l|}{ Amino acid degradation } \\
\hline 2-Methylpropanal & 595 & $\mathrm{a}$ & $0.54 b$ & $0.66 \mathrm{a}$ & $0.39 b$ & 0.17 & $* *$ \\
\hline 3-Methylbutanal & 691 & a & 11.34 & 12.43 & 15.34 & 4.53 & \\
\hline 2-Methylbutanal & 701 & $\mathrm{a}$ & 6.18 & 7.53 & 8.85 & 2.88 & \\
\hline Toluene & 789 & a & 51.99 & 56.94 & 59.18 & 6.88 & \\
\hline 3-Methylbutanol & 795 & a & $7.39 b$ & $8.46 \mathrm{~b}$ & $15.13 \mathrm{a}$ & 5.92 & $*$ \\
\hline 2-Methylbutanol & 797 & a & 1.27 & 1.44 & 1.82 & 5.92 & \\
\hline Pyrrole & 845 & a & 0.31 & 0.30 & 0.25 & 0.05 & \\
\hline 2-Methylpropanoic acid & 868 & a & 2.01 & 1.70 & 2.70 & 1.06 & \\
\hline Ethylbenzene (91) & 884 & $\mathrm{a}$ & $0.09 b$ & $0.18 \mathrm{a}$ & $0.09 b$ & 0.05 & $* *$ \\
\hline 3-Methylbutanoic acid (60) & 942 & a & 2.52 & 2.25 & 2.27 & 1.05 & \\
\hline 2,5- Dimethylpirazine (108) & 943 & a & 0.34 & 0.34 & 0.36 & 0.09 & \\
\hline 2-Methylbutanoic acid & 948 & $\mathrm{a}$ & 2.32 & 2.73 & 2.98 & 1.25 & \\
\hline 2-Acetyl-1-pyrroline & 961 & a & $0.72 b$ & $0.91 b$ & $1.37 \mathrm{a}$ & 0.37 & $* *$ \\
\hline Methional & 986 & a & 0.16 & 0.18 & 0.15 & 0.02 & \\
\hline Benzaldehyde (106) & 1020 & a & 1.14 & 1.40 & 1.27 & 0.33 & \\
\hline Benzeneacetaldehyde & 1110 & a & $6.61 \mathrm{a}$ & $4.14 \mathrm{~b}$ & $2.72 b$ & 3.17 & $*$ \\
\hline Tetramethylpyrazine & 1118 & a & 0.03 & 0.02 & 0.03 & 0.01 & \\
\hline Benzylalcohol (79) & 1122 & a & $0.27 \mathrm{a}$ & $0.18 \mathrm{~b}$ & $0.19 b$ & 0.06 & $* *$ \\
\hline Phenylethyl alcohol (91) & 1195 & a & 0.53 & 0.64 & 0.81 & 0.35 & \\
\hline Total & & & $96.59 b$ & $103.09 \mathrm{ab}$ & $115.63 a$ & 4.55 & $*$ \\
\hline Total microbial metabolism & & & $605.04 \mathrm{~b}$ & $601.91 b$ & $723.03 a$ & 24.32 & $* *$ \\
\hline \multicolumn{8}{|c|}{ Unknown or contaminant compounds } \\
\hline Carbon disulfide (76) & 537 & a & 5.80 & 6.42 & 6.70 & 1.89 & \\
\hline p-Xylene (91) & 892 & a & $0.09 \mathrm{~b}$ & $0.31 \mathrm{a}$ & $0.11 \mathrm{a}$ & 0.09 & $* *$ \\
\hline 2-Butoxyethanol & 953 & a & 2.45 & 2.23 & 2.33 & 0.33 & \\
\hline 4-Methylphenol (108) & 1199 & $\mathrm{a}$ & 0.10 & 0.06 & 0.08 & 0.03 & \\
\hline Total & & & 8.45 & 8.98 & 9.23 & 0.55 & \\
\hline
\end{tabular}

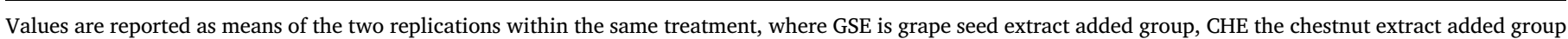
and NIT the control group added with sodium nitrite.

Abundance expressed as AU $\times 10^{\wedge-6}$ (AU: abundance unit, expressed as total ion chromatogram (TIC) or area of the target ion shown in parenthesis).

a Linear retention indices (LRI) of the compounds eluted from the GC-MS using a DB-624 capillary column.

b Reliability of identification: a, identification by mass-spectrum and by coincidence with the LRI of an authentic standard; b, tentatively identification by massspectrum.

c Standard error.

${ }^{\mathrm{d}} \mathrm{P}$ value of natural antioxidant effect ${ }^{* *} p<0.01$, ${ }^{*} p<0.05$, different letters in the same row indicate significant differences at $p<0.05$.

highest for NIT, the lowest in GSE and CHE samples were similar to both. Since the main microbial populations were not examined in this study, the differences in volatile development due to microbial fermentation cannot be explained directly. However, the role of genus staphylococcus in incomplete $\beta$-oxidation are well-known, so the presence of 2-pentanone and 3-octanone were likely related to the presence of these bacteria (Chen, Kong, Han, Xia, \& Xu, 2017).

Contrarily to Chen et al., (2017) and Marco et al. (2006), only one ester was observed. However, they worked on fermented sausages manufactured with starter cultures containing staphylococci strains. Staphylococci promote the formation of esters with staphylococci esterase activity being one of the main factors leading to ester formation in dry-fermented sausages (Wang, Li, Yang, Ruan, \& Sun, 2016).

Among VOCs generated by bacterial metabolism, products of carbohydrate fermentation form an important group, consisting in 13 identified compounds. Acetaldehyde, 2,3-butanedione and 2,3- butanediol were higher in GSE samples than in CHE and NIT; ethyl alcohol and butanoic acid were lowest in NIT samples, while 3-hydroxy-2-butanone was lowest in CHE samples. VOCs from carbohydrate metabolism were generally the highest for GSE. The great abundance of 2butanone is remarkable, considering that this compound is known as a by-product LAB metabolism (Montanari et al., 2018), originating from 2,3-butanedione (significantly higher in GSE). Then, 2-butanone is reduced to 2-butanol and 3-hydroxy-2-butanone, that again, was significantly higher in GSE samples and preferentially formed in small diameter sausages (Montanari et al., 2018).

The last group of VOCs related to bacterial metabolism consisted of 19 VOCs from amino acid degradation. 2-methylpropanal and ethylbenzene were higher in CHE samples, while the lowest amounts of 3methylbutanol and 2-acetyl-1-pyrroline were observed for natural antioxidant products and benzeneacetaldehyde and benzylalcohol were higher in GSE samples than for CHE and NIT. The highest total amino acid degradation products were observed in NIT samples, followed by CHE and then GSE. This was likely due to 3-methylbutanol, whose content almost doubled in NIT samples while toluene, the most abundant compound, was similar for the three groups. The compounds observed are characteristic of dry-fermented sausages, being reported by several authors (Corral et al., 2013; Marco et al., 2006; Škrlep et al., 2017).

Despite the variability within each group of VOCs, total amounts of microbial metabolites suggest a greater development of microflora in NIT samples that might be related to the antimicrobial activity of phenolic extracts during ripening. Several studies have reported phenolic compounds diffuse into bacterial cells walls and interact with cytoplasmatic proteins, affecting Gram positive bacteria and, particularly, Gram positive cocci (Fasolato et al., 2016; Jayaprakasha et al., 2003; Riazi et al., 2018). It is worth noting that the main populations involved in sausage fermentation processes, LAB and Staphylococci, are 
Table 7

Odor active compounds identified by GC-O in Cinta Sense dry-fermented sausages manufactured with natural antioxidant as replacement of sodium nitrite.

\begin{tabular}{|c|c|c|c|c|c|c|c|}
\hline \multirow[t]{2}{*}{ Compound } & \multicolumn{2}{|c|}{ GC-MS $^{1}$} & \multicolumn{2}{|l|}{$\mathrm{GC}^{-\mathrm{O}^{2}}$} & \multirow[t]{2}{*}{$\mathrm{RI}^{3}$} & \multirow[t]{2}{*}{ Odour description } & \multirow[b]{2}{*}{$\mathrm{DF}^{4}$} \\
\hline & LRI & LRI std & LRI initial & LRI final & & & \\
\hline \multicolumn{8}{|l|}{ Lipid auto-oxidation } \\
\hline 1-Propanol & 613 & 611 & 613 & 618 & $\mathrm{a}$ & Vegetal, green, pungent, fresh, floral, & 5 \\
\hline Propanoic acid & 814 & 806 & 800 & 810 & a & Tasty, fresh, green, cheese, cured, pungent & 4 \\
\hline 1-Pentanol & 827 & 823 & 821 & 827 & a & Vegetable, pungent, unpleasant, cabbage, acid & 6 \\
\hline Hexanal & 841 & 839 & 834 & 844 & a & Green, grass, vegetable, fresh & 8 \\
\hline \multicolumn{8}{|l|}{ Spices } \\
\hline Linalool & 1150 & 1145 & 1141 & 1149 & a & Fresh, floral, cabbage, unpleasant, soap & 7 \\
\hline$\beta$-Terpinene $/ \gamma$-Terpinene & 1158 & & 1160 & 1167 & $\mathrm{~b}$ & Cooked, cooked vegetable, floral, pungent, resin & 8 \\
\hline$\beta$-Myrcene & 1003 & 1003 & 1000 & 1004 & a & Irritating, spicy, pepper, green, leaves, earthy & 10 \\
\hline$\alpha$-Terpinene & 1035 & 1035 & 1030 & 1034 & a & Mushrooms, wetness, burnt, unpleasant, pungent, pine, woody, earthy & 12 \\
\hline Unkown terpene & 1075 & & 1076 & 1080 & $\mathrm{c}$ & Earthy, green, vegetable, fresh, fruity, cologne & 5 \\
\hline Terpinolene & 1101 & 1106 & 1107 & 1113 & a & Floral, rose, grass, green & 11 \\
\hline$\alpha$-Thujene & 934 & & 929 & 933 & $\mathrm{c}$ & Sour, vinager, unpleasant, fruity & 5 \\
\hline \multicolumn{8}{|l|}{ Lipid $\beta$-oxidation } \\
\hline 2-Pentanone & 735 & 731 & 725 & 733 & a & Floral, green, fresh, oxidized fat, cheese & 8 \\
\hline \multicolumn{8}{|l|}{ Esterase activity } \\
\hline 3-Methyl-1-butanol acetate & 907 & 905 & 905 & 911 & a & Sweet, fresh, floral & 7 \\
\hline \multicolumn{8}{|l|}{ Carbohydrate fermentation } \\
\hline 2-Butanone & 632 & 629 & 631 & 642 & a & Sweet, slightly unpleasant, green, grass & 5 \\
\hline 2-Butanol & 644 & 643 & 650 & 661 & a & Sweet, caramel, malt, unpleasant & 5 \\
\hline Acetic acid & 720 & 718 & 714 & 722 & a & Grass, vegetable, fresh, wine, green & 5 \\
\hline \multicolumn{8}{|l|}{ Amino acid degradation } \\
\hline 2-Methylpropanal & 595 & 590 & 602 & 609 & a & Acid, floral, green, weak & 4 \\
\hline 3-Methylbutanal & 691 & 687 & 690 & 697 & a & Caramel, chocolate, grass, fresh & 6 \\
\hline 2-Methylbutanal & 702 & 699 & 691 & 700 & a & Sweet, floral, fruity, toasted & 6 \\
\hline 3-Methylbutanol & 795 & 793 & 791 & 793 & a & Sweet, spicy, toasted, floral & 4 \\
\hline 2-Methylpropanoic acid & 868 & 864 & 869 & 872 & a & Cheese, roasted, cured, green, slightly sweet, unpleasant & 6 \\
\hline Ethylbenzene & 884 & 881 & 884 & 891 & a & Earthy, fresh, green, mushroom & 4 \\
\hline 3-Methylbutanoic acid & 942 & 941 & 922 & 926 & a & Cheese, rancid, oxidized fat & 8 \\
\hline 2,5-Dimethylpyrazine & 943 & 943 & 936 & 943 & a & Meaty, cooked potatoes, sweet, buttery & 7 \\
\hline 2-Acetyl-1-pyrroline & 961 & 960 & 960 & 964 & a & Roasted, nuts, bread, pop-corn, biscuits, fried potatoes & 12 \\
\hline Methional & 986 & 964 & 966 & 969 & a & Mashed potato, cooked onion, roasted meat & 9 \\
\hline Tetramethylpyrazine & 1118 & 1118 & 1115 & 1121 & a & Earthy, green, grass, wetness, fresh & 7 \\
\hline \multicolumn{8}{|c|}{ Unknown or contaminant compounds } \\
\hline Carbon Disulfide & 537 & 537 & 531 & 543 & a & Weak, burnt, malt & 4 \\
\hline Unknown & & 776 & 762 & 766 & $\mathrm{c}$ & Cured, meat, acid, fresh, acid & 6 \\
\hline Unknown & 1190 & 1182 & 1176 & 1182 & $\mathrm{c}$ & Roasted, fried nuts, biscuits & 11 \\
\hline
\end{tabular}

1 Linear retention index (LRI) of the compounds eluted from the GC-MS and LRI of standard compound.

2 Initial and end linear retention index of aroma compound in GC-FID-O.

${ }^{3}$ Reliability of identification (RI): (a) identification by mass spectrum, coincidence with LRI of an authentic standard and by coincidence of the assessor's

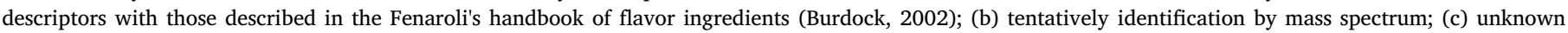
compounds.

4 Detection frequency value.

both Gram positive bacteria.

The role each compound plays in defining the aromatic profile strongly depends on its abundance and on its perception threshold (Olivares et al., 2015). During the GC-O sessions, 31 aroma notes were perceived by trained assessors (Table 7). Seven aroma compounds were associated with spices, 1 to lipid beta-oxidation, 4 to carbohydrate fermentation, 1 to esterase activity, 11 to amino acid degradation, 4 to lipid auto-oxidation, 2 to unknown compounds (not identified with any of the VOCs identified by GC-MS) and 1 to contaminants. Considering their DF value as an aroma impact index, 11 VOCs had a DF higher than 8. Despite the differences outlined by SPME-GC-MS analysis, panelists did not detect any differences in the olfactometric profile of the three groups. This is likely because all the identified VOCs were observed in the three groups and the main differences among GSE, CHE and NIT samples were attributable only to differences in the single compounds abundances. As a consequence, GC-O data were displayed combined in a single aromatic profile (Table 7). Most of the identified compounds were previously observed as recurrent in dry-fermented sausages (Flores \& Olivares, 2015; Schmidt \& Berger, 1998; Söllner \& Schieberle,
2009). Amino acid degradation compounds have a key-role in flavor development, contributing with malty, fruity, sweaty flavors and ripened aroma (Chen et al., 2017; Hospital et al., 2015). Indeed, more than half of SPME-GC-MS identified VOCs were also observed in GC-O sessions as odor active compounds in Cinta Senese dry-fermented sausages. They accounted for one third of the compounds forming the GC$\mathrm{O}$ profile and had high DF values. Among them, 2 acetyl-1-pyrroline and methional are considered as the most potent odor active compounds in dry-fermented sausages (Corral, Leitner, Siegmund, \& Flores, 2016; Söllner \& Schieberle, 2009). Also 3-methylbutanoic acid is considered a potent aroma contributor, giving cheesy, lactic and fatty notes (Flores \& Olivares, 2015), while 2,5-dimethylpyrazine is related to meaty and cooked potatoes notes.

The second most represented VOC group were spice-derived, especially $\alpha$-terpinene, $\beta$-myrcene and terpinolene, which were previously reported as odor active compounds (Olivares et al., 2015; Schmidt \& Berger, 1998). Another important group was composed of lipid oxidation VOCs, among them hexanal was the most potent odorant (Marco, Navarro, \& Flores, 2007; Olivares et al., 2015; Schmidt \& Berger, 1998; 


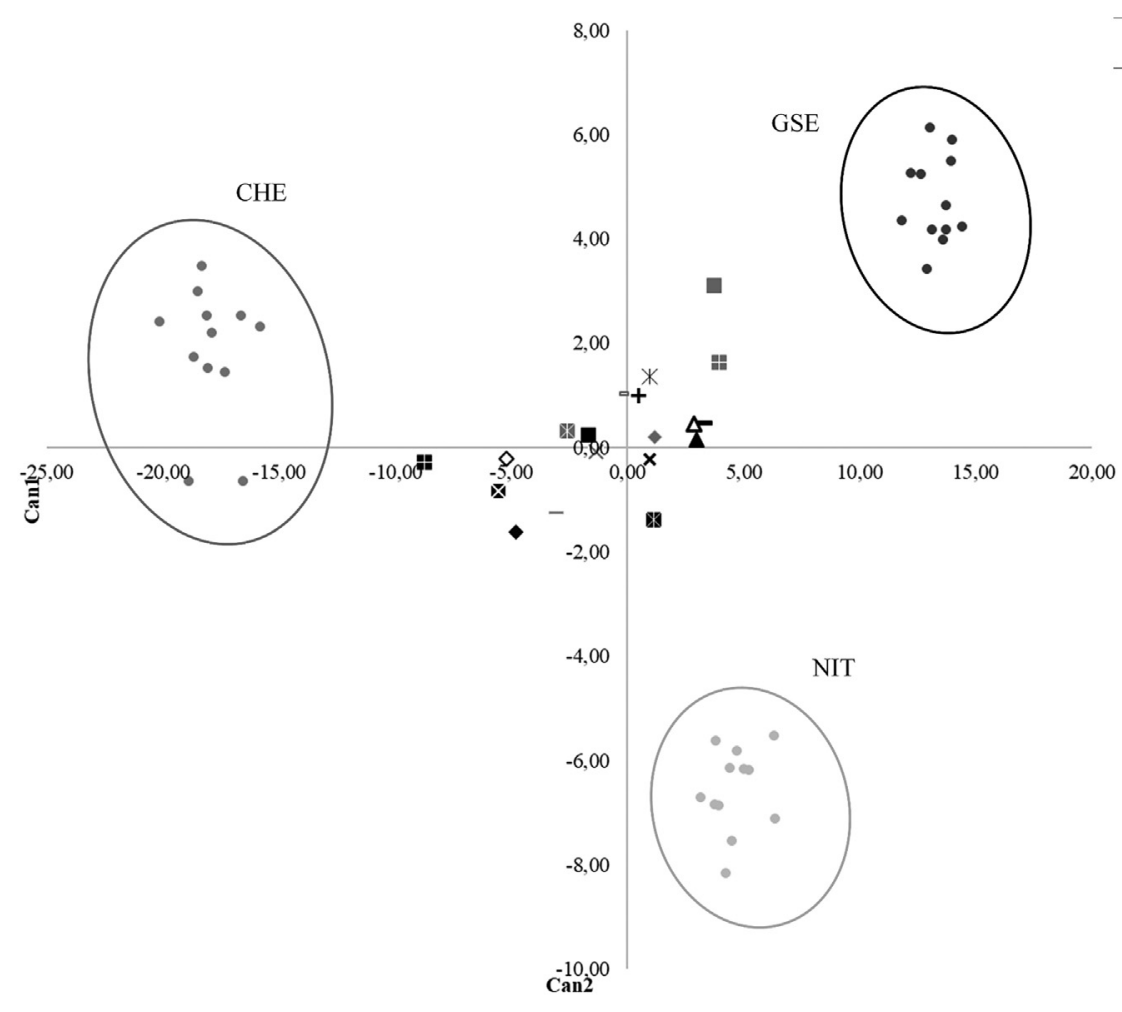

\begin{tabular}{|c|c|c|c|c|}
\hline & Volatile compounds & Origin & Can1 & Can2 \\
\hline * & 2-Pentanone & Lipid $\beta$-oxidation & 1.12 & -1.40 \\
\hline+ & Propanoic acid & Lipid auto-oxidation & 0.47 & 0.99 \\
\hline $\mathbf{x}$ & 3-Octanone & Lipid $\beta$-oxidation & -5.56 & -0.85 \\
\hline$\Delta$ & Acetaldehyde & Carbohydrate fermentation & 2.96 & 0.15 \\
\hline$x$ & 1-Butanol & Carbohydrate fermentation & 0.97 & -0.23 \\
\hline$\bullet$ & 3-Methyl-butanol & Amino acid degradation & -4.79 & -1.63 \\
\hline - & 2-Methyl-butanol & Amino acid degradation & 3.27 & 0.48 \\
\hline $\mathbf{\square}$ & Pyrrole & Amino acid degradation & -1.67 & 0.24 \\
\hline$\diamond$ & Ethylbenzene & Amino acid degradation & -5.23 & -0.22 \\
\hline$\Delta$ & 2,5-Dimethylpyrazine & Amino acid degradation & 2.87 & 0.45 \\
\hline * & Benzeneacetaldehyde & Amino acid degradation & 0.95 & 1.37 \\
\hline * & Hexane & Lipid auto-oxidation & -2.58 & 0.31 \\
\hline 패 & Octane & Lipid auto-oxidation & 3.96 & 1.63 \\
\hline$=$ & 1-Pentanol & Lipid auto-oxidation & -0.32 & 1.04 \\
\hline- & Hexanal & Lipid auto-oxidation & -3.05 & -1.26 \\
\hline$\bullet$ & 1-Hexanol & Lipid auto-oxidation & 1.16 & 0.19 \\
\hline$\square$ & Decane & Lipid auto-oxidation & 3.75 & 3.09 \\
\hline H & Tetradecane & Lipid auto-oxidation & -8.76 & -0.29 \\
\hline$x$ & Tetramethylpyrazine & Amino acid degradation & -1.36 & -0.09 \\
\hline & Proporti & aria & 0.88 & $\mathbf{0 . 1 2}$ \\
\hline
\end{tabular}

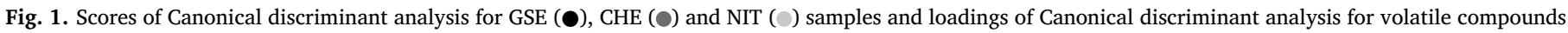
identified by Stepwise discriminant analysis.

Söllner \& Schieberle, 2009). Indeed, hexanal produces fresh and green notes (Table 7), but it turns to rancid notes as its abundance increases. Lastly, also 2,3-butanedione, derived from carbohydrate fermentation, due to its low threshold (about $4 \mu \mathrm{g} / \mathrm{l}$ ) (Hospital et al., 2015), was an important aroma contributor, characterized by buttery-sweet notes and a DF of 10.

Figure 1 displays the 19 compounds identified by SDA. The selected compounds were able to discriminate the three treatments. Can1 accounted for a great part of variance, separating CHE from GSE and NIT, while Can 2 sharply divided GSE and CHE from NIT. Multivariate analysis showed how lipid auto-oxidation compounds, comprising half of the compounds identified by SDA, were central in differentiating the three groups. Tetradecane, ethylbenzene and 3-octanone having the greatest negative Can1 scores, were considered mainly responsible for separating GSE and NIT from CHE, in agreement with ANOVA results. Concerning Can2, compounds with higher weighing were decane and octane for GSE and CHE, while 3-methylbutanol seems to characterize NIT samples. Among the 19 compounds identified, 8 were also perceived by GC-O panelists. However, considering their DF and CCs together, only hexanal and 2.5-dimethylpyrazine might have an effective potential in discriminating the groups also from a sensory point of view.

\subsection{Sensory analysis}

Figure 2 shows sensory results. Abnormal colors, off-flavors, offodors and rancid were scored as 0 (not present) and were not shown. As expected, the most affected traits were color related, with both color uniformity $(P<0.01)$ and redness $(P<0.01)$ scoring lower for GSE and CHE samples compared to NIT ones, while firmness was was scored highest for CHE samples $(P<0.05)$, agreeing with TPA results. Likely, the lower moisture and fat contents observed in CHE could have affected the firmness, even if neither moisture nor fat, significantly differed among treatments. Despite the differences in lipid auto-oxidation VOCs, no perceivable rancid notes were detected by panelists, as the level of MDA found in the samples did not exceed the organoleptic perception of lipid oxidation (Campo et al., 2006). Effects of adding grape seed and chestnut extracts to dry-fermented sausages have not, however, always been positive. Ribas-Agustí et al. (2014) reported that panelists discarded grape seed extract added products, as there were judged to be abnormal compared to control samples. Similarly, Özvural and Vural (2011) observed a decrease in overall acceptability of frankfurters with grape seed extract added, even when products manufactured with concentrations lower than $0.05 \%$ resulted in scores similar to control.

\section{Conclusions}

The results on VOCs profiles suggested a greater antimicrobial activity of natural antioxidant mixtures (GSE and CHE) compared to sodium nitrite (NIT), likely due to their phenolic constituents; further none of the main foodborne pathogens were found in any sample. No significant differences among treatments were found for lipid oxidation, even if lipid auto-oxidation VOCs suggested a slightly lower antioxidant activity of GSE and CHE compared to sodium nitrite. Despite the differences in single VOCs abundances, the replacement did not affect the overall aroma profile, as outlined by GC-O results and sensory analysis. Some differences in instrumental color and texture negatively affected GSE and CHE products, but the overall acceptability was not influenced. GSE and CHE effects on microbiota in dry-fermented sausages should be studied in depth, however, the results so far indicated that tested antioxidants are valid alternatives to sodium nitrite in Cinta Senese dryfermented sausages.

\section{Acknowledgments}

The research was carried out with funds from the European Union's Horizon 2020 research and innovation program under grant agreement No 634476 (acronym TREASURE). The content of this works reflects 


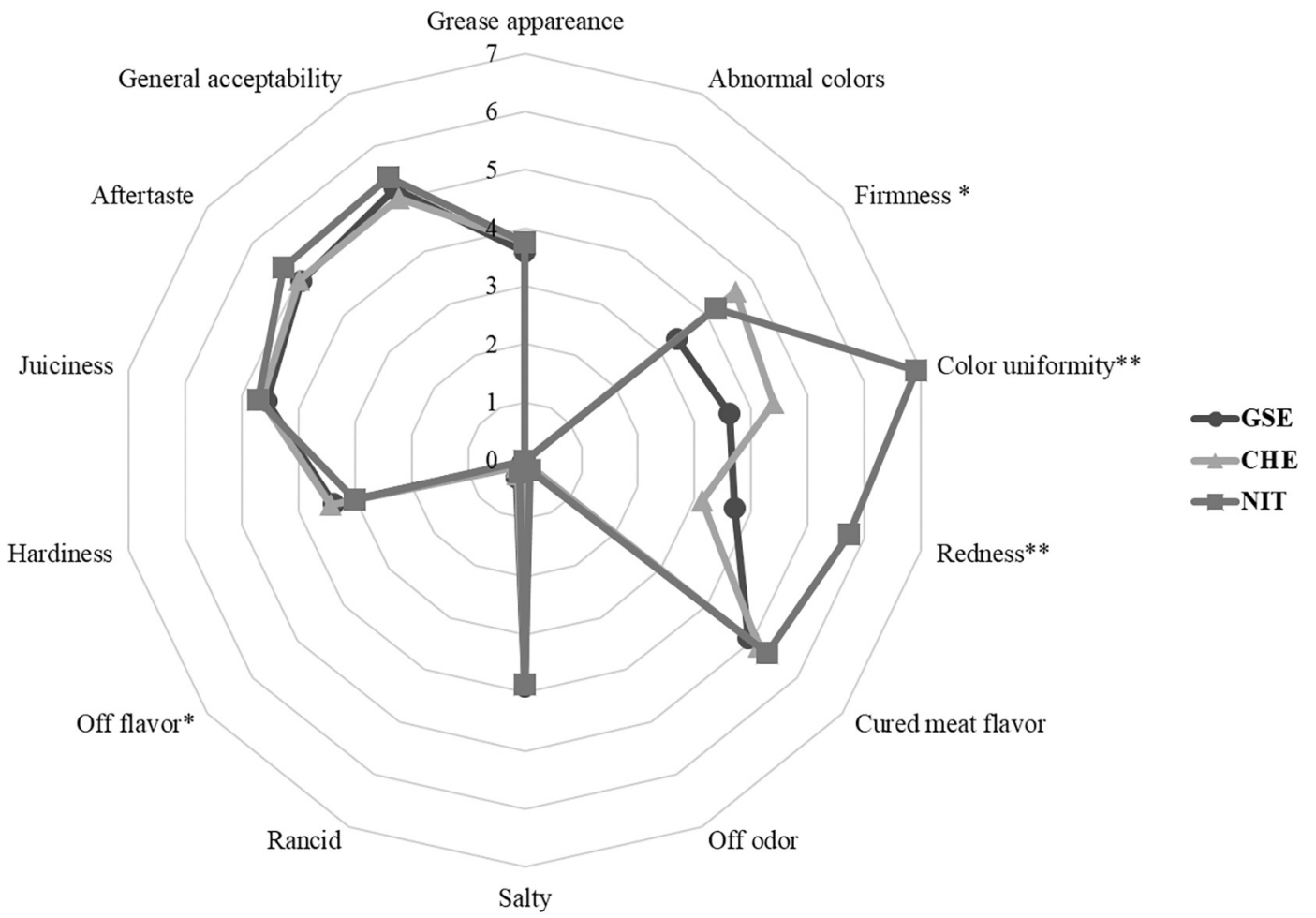

Fig. 2. Sensorial traits of Cinta Sense dry-fermented sausages manufactured with natural antioxidant as replacement of sodium nitrite.

only the author's view and the European Union Agency is not responsible for any use that may be made of the information it contains. We acknowledge Prof. Romani and Phytolab for providing the antioxidant mixtures. Authors also acknowledge the financial support of AGL2015-64673-R (MINEICO, Spain) and FEDER funds.

\section{References}

Burdock, G. A. (2010). Fenaroli's handbook of flavor ingredients.

Campo, M. M., Nute, G. R., Hughes, S. I., Enser, M., Wood, J. D., \& Richardson, R. I. (2006). Flavour perception of oxidation in beef. Meat Science, 72, 303-311.

Chen, Q., Kong, B., Han, Q., Xia, X., \& Xu, L. (2017). The role of bacterial fermentation in lipolysis and lipid oxidation in Harbin dry sausages and its flavour development. LWT - Food Science and Technology, 77, 389-396.

Cofrades, S., Salcedo Sandoval, L., Delgado-Pando, G., López-López, I., Ruiz-Capillas, C., \& Jiménez-Colmenero, F. (2011). Antioxidant activity of hydroxytyrosol in frankfurters enriched with n-3 polyunsaturated fatty acids. Food Chemistry, 129, 429-436.

Corral, S., Leitner, E., Siegmund, B., \& Flores, M. (2016). Determination of sulfur and nitrogen compounds during the processing of dry fermented sausages and their relation to amino acid generation. Food Chemistry, 190, 657-664.

Corral, S., Salvador, A., \& Flores, M. (2013). Salt reduction in slow fermented sausages affects the generation of aroma active compounds. Meat Science, 93, 776-785.

De Mey, E., De Maere, H., Paelinck, H., \& Fraeye, I. (2017). Volatile N-nitrosamines in meat products: Potential precursors, influence of processing, and mitigation strategies. Critical Reviews in Food Science and Nutrition, 57, 2909-2923.

van Den Dool, H., \& Dec. Kratz, P. (1963). A generalization of the retention index system including linear temperature programmed gas-liquid partition chromatography. Journal of Chromatography A, 11, 463-471.

Falowo, A. B., Fayemi, P. O., \& Muchenje, V. (2014). Natural antioxidants against lipidprotein oxidative deterioration in meat and meat products: A review. Food Research International, 64, 171-181.

Fasolato, L., Carraro, L., Facco, P., Cardazzo, B., Balzan, S., Taticchi, A., ... Novelli, E. (2016). Agricultural by-products with bioactive effects: A multivariate approach to evaluate microbial and physicochemical changes in a fresh pork sausage enriched with phenolic compounds from olive vegetation water. International Journal of Food Microbiology, 228, 34-43.

Flores, J. (1997). Mediterranean vs northern European meat products. Processing technologies and main differences. Food Chemistry, 59, 505-510.

Flores $\mathrm{M}$ and Olivares A 2015. (25 25.1 Flavors).

Flores, M., Olivares, A., Chen, M., Tu, R., \& Wang, S. (2015). Handbook of fermented meat and poultry. Oxford, UK: Blackwell Publishing Ltd.

Hammes, W. P. (2012). Metabolism of nitrate in fermented meats: The characteristic feature of a specific group of fermented foods. Food Microbiology, 29, 151-156.

Hospital, X. F., Carballo, J., Fernández, M., Arnau, J., Gratacós, M., \& Hierro, E. (2015). Technological implications of reducing nitrate and nitrite levels in dry-fermented sausages: Typical microbiota, residual nitrate and nitrite and volatile profile. Food Control, 57, 275-281.

Hygreeva, D., Pandey, M. C., \& Radhakrishna, K. (2014). Potential applications of plant based derivatives as fat replacers, antioxidants and antimicrobials in fresh and processed meat products. Meat Science, 98, 47-57.

Jayaprakasha, G. K., Selvi, T., \& Sakariah, K. K. (2003). Antibacterial and antioxidant activities of grape (Vitis vinifera) seed extracts. Food Research International, 36, 117-122.

Kao, T. T., Tu, H. C., Chang, W. N., Chen, B. H., Shi, Y. Y., Chang, T. C., \& Fu, T. F. (2010). Grape seed extract inhibits the growth and pathogenicity of Staphylococcus aureus by interfering with dihydrofolate reductase activity and folate-mediated one-carbon metabolism. International Journal of Food Microbiology, 141, 17-27.

Liu, H., Zeng, F., Wang, Q., Ou, S., Tan, L., \& Gu, F. (2013). The effect of cryogenic grinding and hammer milling on the flavour quality of ground pepper (Piper nigrum L.). Food Chemistry, 141, 3402-3408.

Lorenzo, J. M., González-Rodríguez, R. M., Sánchez, M., Amado, I. R., \& Franco, D. (2013). Effects of natural (grape seed and chestnut extract) and synthetic antioxidants (buthylatedhydroxytoluene, BHT) on the physical, chemical, microbiological and sensory characteristics of dry cured sausage "chorizo. Food Research International, 54, 611-620.

Lücke, F. K. (2000). Utilization of microbes to process and preserve meat. Meat Science, $56,105-115$.

Marco, A., Navarro, J. L., \& Flores, M. (2006). The influence of nitrite and nitrate on microbial, chemical and sensory parameters of slow dry fermented sausage. Meat Science, 73, 660-673.

Marco, A., Navarro, J. L., \& Flores, M. (2007). Quantitation of selected odor-active constituents in dry fermented sausages prepared with different curing salts. Journal of Agricultural and Food Chemistry, 55, 3058-3065.

Montanari, C., Gatto, V., Torriani, S., Barbieri, F., Bargossi, E., Lanciotti, R., ... Gardini, F. (2018). Effects of the diameter on physico-chemical, microbiological and volatile profile in dry fermented sausages produced with two different starter cultures. Food Bioscience, 22, 9-18.

Moretti, V. M., Madonia, G., Diaferia, C., Mentasti, T., Paleari, M. A., Panseri, S., ... Gandini, G. (2004). Chemical and microbiological parameters and sensory attributes of a typical Sicilian salami ripened in different conditions. Meat Science, 66, 845-854.

Mujić, I., Rudić, D., Živković, J., Jukić, H., Jug, T., Nikolić, G., \& Trutić, N. (2014). Antioxidant and antibacterial properties of castanea sativa mill, Catkins extracts. Acta horticulturae, 1043, 167-173.

Olivares, A., Navarro, J. L., \& Flores, M. (2011). Effect of fat content on aroma generation during processing of dry fermented sausages. Meat Science, 87, 264-273.

Olivares, A., Navarro, J. L., \& Flores, M. (2015). Characterization of volatile compounds responsible for the aroma in naturally fermented sausages by gas chromatographyolfactometry. Food Science and Technology International, 21, 110-123.

Orav, A., Stulova, I., Kailas, T., \& Müürisepp, M. (2004). Effect of storage on the essential oil composition of Piper nigrum L. fruits of different ripening states. Journal of Agricultural and Food Chemistry, 52, 2582-2586.

Özvural, E. B., \& Vural, H. (2011). Grape seed flour is a viable ingredient to improve the 
nutritional profile and reduce lipid oxidation of frankfurters. Meat Science, 88 , 179-183.

Özvural, E. B., \& Vural, H. (2014). Which is the best grape seed additive for frankfurters: Extract, oil or flour? Journal of the Science of Food and Agriculture, 94, 792-797.

Pateiro, M., Bermúdez, R., Lorenzo, J., \& Franco, D. (2015). Effect of addition of natural antioxidants on the shelf-life of 'chorizo', a spanish dry-cured sausage. Antioxidants, 4, $42-67$.

Pugliese, C., \& Sirtori, F. (2012). Quality of meat and meat products produced from southern European pig breeds. Meat Science, 90(3), 511-518.

Pugliese, C., Sirtori, F., D'Adorante, S., Parenti, S., Rey, A., Lopez-bote, C., \& Franci, O. (2010). Effect of pasture in oak and chestnut groves on chemical and sensorial traits of cured lard of Cinta Senese pigs. Italian Journal of Animal Science, 8, 131-142.

Purriños, L., García Fontán, M. C., Carballo, J., \& Lorenzo, J. M. (2013). Study of the counts, species and characteristics of the yeast population during the manufacture of dry-cured ' lacón' effect of salt level. Food Microbiology, 34, 12-18.

Riazi, F., Zeynali, F., Hoseini, E., Behmadi, H., \& Savadkoohi, S. (2018). Corrigendum to 'Oxidation phenomena and color properties of grape pomace on nitrite-reduced meat emulsion systems'. [Meat Sci. (121) (2016) 350-358], (S0309174016302182) Meat Science, 135, 189. https://doi.org/10.1016/j.meatsci.2016.07.008.

Ribas-Agustí, A., Gratacós-Cubarsí, M., Sárraga, C., Guàrdia, M. D., García-Regueiro, J. A. \& Castellari, M. (2014). Stability of phenolic compounds in dry fermented sausages added with cocoa and grape seed extracts. LWT - Food Science and Technology, 57, 329-336.

Schmidt, S., \& Berger, R. G. (1998). Aroma compounds in fermented sausages of different origins. LWT - Food Science and Technology, 31, 559-567.
Shah, M. A., Bosco, S. J. D., \& Mir, S. A. (2014). Plant extracts as natural antioxidants in meat and meat products. Meat Science, 98, 21-33.

Sirtori, F., Crovetti, A., Acciaioli, A., Bonelli, A., Pugliese, C., Bozzi, R., ... Franci, O. (2015). Effect of replacing a soy diet with Vicia faba and Pisum sativum on performance, meat and fat traits of Cinta Senese pigs. Italian Journal of Animal Science, 14, 3659.

Škrlep, M., Čandek-Potokar, M., Tomažin, U., Batorek Lukač, N., \& Flores, M. (2017). Properties and aromatic profile of dry-fermented sausages produced from Krškopolje pigs reared under organic and conventional rearing regime. Animal, 1-8.

Söllner, K., \& Schieberle, P. (2009). Decoding the key aroma compounds of a Hungariantype salami by molecular sensory science approaches. Journal of Agricultural and Food Chemistry, 57, 4319-4327.

Toldrá, F., \& Flores, M. (2014). Sausages, types of | dry and semidry. Encyclopedia of meat sciences (pp. 248-255). Elsevier.

Vyncke, W. (1970). Direct determination of the thiobarbituric acid value in trichloracetic acid extracts of fish as a measure of oxidative rancidity. Fette, Seifen, Anstrichmittel, $72,1084-1087$.

Wakamatsu, J., Nishimura, T., \& Hattori, A. (2004). A Zn-porphyrin complex contributes to bright red color in Parma ham. Meat Science, 67, 95-100.

Wakamatsu, J., Okui, J., Ikeda, Y., Nishimura, T., \& Hattori, A. (2004). Establishment of a model experiment system to elucidate the mechanism by which Zn-protoporphyrin IX is formed in nitrite-free dry-cured ham. Meat Science, 68, 313-317.

Wang, Y., Li, Y., Yang, J., Ruan, J., \& Sun, C. (2016). Microbial volatile organic compounds and their application in microorganism identification in foodstuff. TrAC Trends in Analytical Chemistry, 78, 1-16. 